\title{
IMPROVING PREDICTIONS OF LEAF APPEARANCE IN FIELD GROWN POTATO
}

\author{
Nereu Augusto Streck ${ }^{1 *}$; Isabel Lago²; Fabiana Luiza Matielo de Paula³; Dilson Antônio \\ Bisognin $^{1}$; Arno Bernardo Heldwein ${ }^{1}$ \\ ${ }^{1}$ UFSM - Depto. de Fitotecnia, 97105-900 - Santa Maria, RS - Brasil. \\ ${ }^{2}$ UFSM - Graduando em Agronomia, $97105-900$ - Santa Maria, RS - Brasil. \\ ${ }^{3}$ UFSM - Programa de Pós-Graduação em Agronomia. \\ *Corresponding author 〈nstreck1@smail.ufsm.br>
}

\begin{abstract}
The calculation of leaf appearance rate (LAR) and number of accumulated or emerged leaves (NL) on the main stem are part of many crop simulation models. The purpose of this study was to adapt and evaluate a model (WE model) for simulating the main stem LAR and NL in potato (Solanum tuberosum L.). The WE model is a non-linear multiplicative model that takes into account the effect of genotype and environmental factors on LAR. A linear model (Phyllochron model) was also used as a comparison with the WE model. A series of field experiments with 14 planting dates over two years (2003 and 2004) was carried out in Santa Maria, RS, Brazil, using the cultivar Asterix. Coefficients of the WE model and the phyllochron model were estimated with data from four planting dates in 2003, and the models were validated with data from the other ten plantings, which are independent data. The statistics used to quantify model performance was the root mean square error (RMSE). The WE model was a better predictor of NL (RMSE=2.0 leaves) than the phyllochron model (RMSE=3.7 leaves). The WE model has coefficients with biological meaning and a non-linear temperature response function, which renders generality and robustness to this LAR model.
\end{abstract}

Key words: modeling, temperature, leaf development, phyllochron

\section{MELHORA NA PREDIÇÃO DO APARECIMENTO DE FOLHAS EM BATATA CULTIVADA A CAMPO}

\begin{abstract}
RESUMO: O cálculo da taxa de aparecimento de folhas (LAR) e do número de folhas acumuladas ou emergidas (NL) na haste principal são parte de muitos modelos de simulação de cultivos agrícolas. O objetivo deste estudo foi adaptar e avaliar um modelo (modelo WE) para simular a LAR e o NL na haste principal de batata (Solanum tuberosum L.). O modelo WE é um modelo multiplicativo não linear que leva em conta o efeito do genótipo e de fatores ambientais sobre LAR. Um modelo linear (modelo do filocrono) também foi usado como comparação com o modelo WE. Uma série de experimentos de campo com 14 épocas de plantio durante dois anos (2003 e 2004) foi conduzido em Santa Maria, RS. A cultivar usada foi Asterix. Os coeficientes dos modelos WE e filocrono foram estimados com dados de quarto épocas de plantio em 2003 e os modelos foram avaliados com dados independentes de outras dez épocas de plantio. A estatística usada para quantificar o desempenho dos dois modelos foi a raiz do quadrado médio do erro (RMSE). O modelo WE foi um melhor preditor de NL (RMSE=2,0 folhas) do que o modelo filocrono (RMSE=3,7 folhas). O modelo WE tem coeficientes com significado biológico e uma função não linear de resposta a temperatura que conferem generalidade e robustes a este modelo de LAR.

Palavras-chave: modelagem, temperatura, desenvolvimento folhar, filocrono
\end{abstract}

\section{INTRODUCTION}

Potato (Solanum tuberosum L.), Solanaceae family, is native of South America and had its worldwide distribution from Europe at the end of the $16^{\text {th }}$ century (Hawkes, 1990; 1994). In a time frame of about 300 years, potato has arisen from a little known crop in the Andes of South America to become the fourth most important food crop (Hawkes, 1994; Manrique, 2000; Nyende et al., 2005), with an annual world production of about 320 million metric tons (FAO, 2005). Potato is the main horticultural crop in Brazil in area and food preference, with about $98 \%$ of the producing areas located in Southern States of Minas Gerais, São Paulo, Paraná, and Rio Grande do Sul (Lopes \& Buso, 1997; IBGE, 2004).

Calculation of leaf appearance rate (LAR) is an important part of many crop simulation models (Hodges, 1991). The integration of LAR over time gives the number of accumulated or emerged leaves 
on a main stem (NL), which is an excellent measure of plant development. The NL is related to the timing of several developmental stages of many agricultural crops (Lee et al., 2001; Streck et al., 2003a; Fortsthofer et al., 2004) including potato (Bätz et al., 1980). For instance, branching begins in potato when a certain NL are emerged on the main stem (Bätz et al., 1980; Vos \& Biemond, 1992). Leaf area that intercepts and absorbs solar radiation for canopy photosynthesis, which impacts dry matter production and crop yield is also related to NL (Streck et al., 2003a; 2003b).

Temperature is a major environmental factor that drives leaf appearance in potato (Vos \& Biemond, 1992; Cao \& Tibbitts, 1995). One approach to predict the appearance of individual leaves is to use the phyllochron concept, defined as the time interval between the appearance of successive leaf tips (Klepper et al., 1982; Kirby, 1995; Wilhelm \& McMaster, 1995). The time needed for the appearance of one leaf can be expressed in thermal time (TT), measured in units of degree days $\left({ }^{\circ} \mathrm{C}\right.$ day). Therefore, the phyllochron has units of ${ }^{\circ} \mathrm{C}$ day leaf ${ }^{1}$. However, the TT approach may be subject to criticism because there are different ways to calculate TT, which can cause different results from the same data set (McMaster \& Wilhelm, 1997) and because of the assumption of a linear response of development to temperature, which is not completely realistic from a biological point of view (Shaykewich, 1995; Xue et al., 2004).

One way to overcome some of the disadvantages of the TT approach is to use non-linear temperature response functions and multiplicative models. One example of the latter type of model is the Wang and Engel (WE) (Wang \& Engel, 1998). Xue et al. (2004) demonstrated that the predictions of leaf appearance in several winter wheat cultivars were improved with the WE model compared with the phyllochron model. However, the WE model has been used to simulate LAR in crops where the reproductive organs are above ground like wheat (Wang \& Engel, 1998; Streck et al., 2003b), not in potato, which constituted the rationale for this research effort.

The objective of this study was to adapt and evaluate the WE model for simulating the main stem LAR and NL in potato.

\section{MATERIAL AND METHODS}

\section{The WE model}

The WE model (Wang \& Engel, 1998) for leaf appearance rate in potato has the general form:

$$
\mathrm{LAR}=\mathrm{LAR}_{\text {max }} \mathrm{f}(\mathrm{T})
$$

where LAR is the daily leaf appearance rate (leaves day $\left.^{-1}\right), \mathrm{LAR}_{\text {max }}$ is the maximum daily leaf appearance rate (leaves day ${ }^{-1}$ ) under optimum temperature and $f(T)$ is a dimensionless temperature response function (01) for LAR. The $f(T)$ is a beta function: $\mathrm{f}(\mathrm{T})=\left[2\left(\mathrm{~T}-\mathrm{T}_{\min }\right)^{\alpha}\left(\mathrm{T}_{\mathrm{opt}}-\mathrm{T}_{\min }\right)^{\alpha}-\left(\mathrm{T}-\mathrm{T}_{\min }\right)^{2 \alpha}\right] /\left(\mathrm{T}_{\mathrm{opt}}-\mathrm{T}_{\min }\right)^{2 \alpha}$ for
$\mathrm{Tmin} \leq \mathrm{T} \leq \mathrm{Tmax}$

$\mathrm{f}(\mathrm{T})=0 \quad$ for $\mathrm{T}<\mathrm{Tmin}$ or $\mathrm{T}>\mathrm{Tmax}$

$\alpha=\ln 2 / \ln \left[\left(\mathrm{T}_{\max }-\mathrm{T}_{\min }\right) /\left(\mathrm{T}_{\mathrm{opt}}-\mathrm{T}_{\min }\right)\right]$

where $\mathrm{T}_{\text {min }}, \mathrm{T}_{\text {opt }}$, and $\mathrm{T}_{\text {max }}$ are the cardinal temperatures (minimum, optimum, and maximum) for LAR of potato and $\mathrm{T}$ is the mean daily temperature calculated from the average of minimum and maximum air temperatures. The minimum, optimum, and maximum cardinal temperatures for LAR of potato were taken as $7^{\circ} \mathrm{C}, 21^{\circ} \mathrm{C}$, and $30^{\circ} \mathrm{C}$ (Sands et al., 1979). The curve generated by equations (2) and (3) with these cardinal temperatures for LAR of potato is plotted in Figure 1. The main stem number of emerged leaves is calculated by accumulating daily LAR (i. e. at a one day time step) starting at emergence, i.e. $\mathrm{NL}=\sum \mathrm{LAR}$.

\section{The phyllochron model}

A second model evaluated in this study was the phyllochron model (Klepper et al., 1982; Kirby, 1995; Wilhelm \& McMaster, 1995) using the thermal time approach. This model was also evaluated because it is widely used to simulate leaf appearance in several agricultural crops (McMaster et al., 1991; Matthews \& Hunt, 1994; Lee et al., 2001; Fortsthofer et al., 2004; McMaster, 2005). Daily values of thermal time (TT, ${ }^{\circ} \mathrm{C}$ day) (Gilmore \& Rogers, 1958; Arnold, 1960; Matthews \& Hunt, 1994) were calculated as:

$\mathrm{TT}=(\mathrm{T}-\mathrm{Tmin}) .1$ day

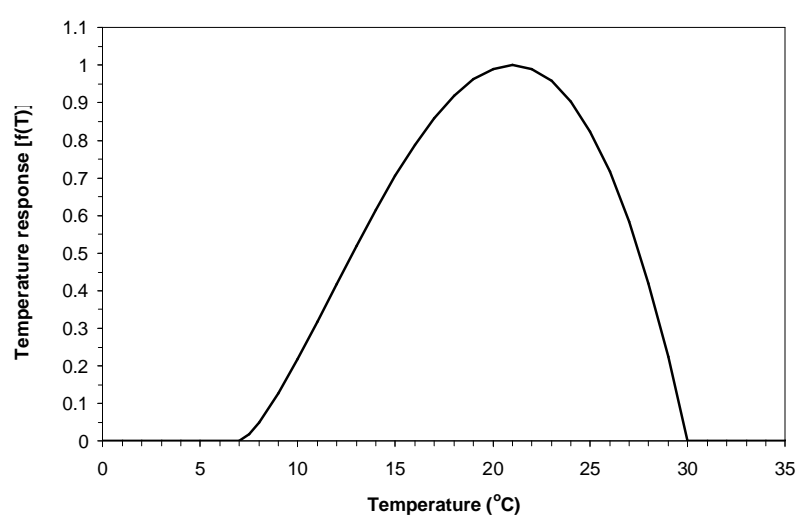

Figure 1 - The temperature response function (equations 2 and 3 ) of the WE leaf appearance model with cardinal temperatures for leaf appearance in potato, cv. Asterix, of $7^{\circ} \mathrm{C}$ for Tmin, $21^{\circ} \mathrm{C}$ for Topt, and $30^{\circ} \mathrm{C}$ for Tmax. 
when $\mathrm{Tmin}<\mathrm{T} \leq \mathrm{Topt}$ and if $\mathrm{T}<\mathrm{Tmin}$ then $\mathrm{T}=\mathrm{Tmin}$,

TT=[(Topt-Tmin).(Tmax-T)/(Tmax-Tot) $] .1$ day

when Topt $<\mathrm{T} \leq \mathrm{T} \max$ and if $\mathrm{T}>\mathrm{T} \max$ then $\mathrm{T}=\mathrm{T} \max$

where Tmin, Topt, Tmax and $\mathrm{T}$ have been defined in equations (2) and (3). Values of Tmin, Topt and Tmax have also been previously defined. The schematic representation of this thermal time approach is in Figure 2 . The accumulated thermal time (ATT) from emergence was calculated by accumulating TT, i.e. $\mathrm{ATT}=\sum \mathrm{TT}$.

\section{Field experiments}

A series of experiments were conducted in Santa Maria RS, Brazil, (29 $43^{\prime} \mathrm{S}$; 53 $3^{\circ} 43^{\prime} \mathrm{W}$, and altitude: $95 \mathrm{~m}$ ). A total of 14 planting dates over two years, 2003 and 2004 (Table 1), was carried out to evaluate the influence of varying air temperature on LAR of the potato cultivar Asterix, a potato cultivar widely grown in Southern Brazil.

Soil tests in the $0-30 \mathrm{~cm}$ layer indicated $2.2 \%$ organic matter, $3.2 \mathrm{ppm}$ of P, and $46.0 \mathrm{ppm}$ of K. Soil at the experimental site was a Rhodic Paleudalf. Fertilization rates at planting in both years were $105 \mathrm{Kg}$ $\mathrm{ha}^{-1}$ of $\mathrm{N}, 165 \mathrm{Kg} \mathrm{ha}^{-1}$ of P, and $135 \mathrm{Kg} \mathrm{ha}^{-1}$ of K. Nitrogen dressing was $45 \mathrm{Kg} \mathrm{ha}^{-1}$ of $\mathrm{N}$ at tuber initiation (Westermann \& Kleinkopf, 1985). At all planting dates, virus free and high physiological quality tubers from the Potato Breeding and Genetic Program of Federal University of Santa Maria (UFSM) were used. The experimental design was randomized complete blocks with four replicates. Each plot had four rows of $3.0 \mathrm{~m}$ in an N-S direction. Tubers were planted at a row spacing of $0.75 \mathrm{~m}$ and $0.33 \mathrm{~m}$ within rows. The two outside rows were border rows. In order to minimize biotic stresses as much as possible, diseases and insects

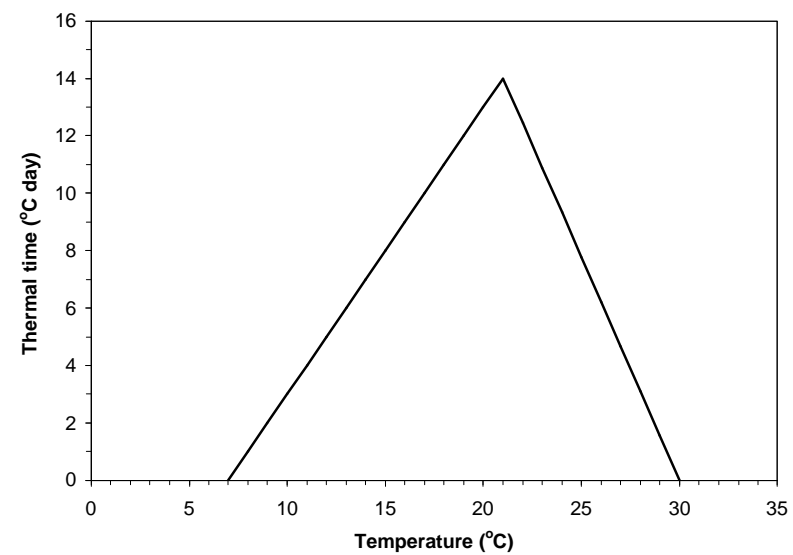

Figure 2 - Method of calculating daily values of thermal time (equations 4 and 5) for leaf appearance in potato, cv. Asterix.
Table 1 - Dates (month/day/year) of planting and emergence of the potato cv. Asterix used in the study. Santa Maria, RS, Brazil, 2003-2004.

\begin{tabular}{lcc}
\hline Planting & Planting date & Emergence date \\
\hline 1 & $01 / 21 / 2003$ & $02 / 13 / 2003$ \\
2 & $02 / 12 / 2003$ & $02 / 25 / 2003$ \\
3 & $02 / 28 / 2003$ & $03 / 11 / 2003$ \\
4 & $03 / 27 / 2003$ & $04 / 07 / 2003$ \\
\hline 5 & $08 / 12 / 2003$ & $09 / 12 / 2003$ \\
6 & $09 / 15 / 2003$ & $10 / 06 / 2003$ \\
7 & $10 / 15 / 2003$ & $11 / 03 / 2003$ \\
8 & $11 / 20 / 2003$ & $12 / 08 / 2003$ \\
9 & $12 / 24 / 2003$ & $01 / 27 / 2004$ \\
10 & $01 / 28 / 2004$ & $02 / 15 / 2004$ \\
11 & $02 / 27 / 2004$ & $03 / 14 / 2004$ \\
12 & $03 / 26 / 2004$ & $04 / 10 / 2004$ \\
13 & $04 / 26 / 2004$ & $05 / 06 / 2004$ \\
14 & $08 / 26 / 2004$ & $09 / 06 / 2004$ \\
\hline
\end{tabular}

were prevented by spraying recommended fungicides and insecticides, while weeds were manually controlled. Furrow irrigation was applied only in January 2004 when rainfall was not enough to prevent water stress. Other agronomic practices, such as hilling, were performed as recommended for local conditions (Bisognin, 1996).

Emergence was measured in each plot by counting the number of emerged plants on a daily basis for all plants in each plot. Emergence date was considered when $50 \%$ of the plants were emerged from the soil surface (Sands et al., 1979). Shortly after emergence, six plants of the center two rows (three plants per row) in each plot were randomly tagged with colored wires. These plants were used to record the number of unfolded visible leaves on one main stem per mother tuber, twice a week. A leaf was assumed visible when its apical leaflet was $1 \mathrm{~cm}$ in length (Cao \& Tibbitts, 1995).

Daily minimum and maximum air temperature, and precipitation were measured by a standard meteorological station located at about $200 \mathrm{~m}$ from the plots.

\section{Model coefficient estimates}

The $\mathrm{LAR}_{\max }$ in the WE model (eq. 1) was estimated from NL data collected in plantings 1 to 4 (21 Jan. 2003, 12 Feb. 2003, 28 Feb. 2003, and 27 Mar. 2003 ) by changing (increasing and decreasing) an initial value (1.0 leaves day ${ }^{-1}$ ) by a $5 \%$ step until obtaining the best fit between observed and estimated NL values by minimizing the root mean square error (RMSE, eq. 6). The estimated LARmax was 0.872 $( \pm 0.130)$ leaves day ${ }^{-1}$. The phyllochron was estimated 
by the inverse of the slope of the linear regression of NL against ATT (Klepper et al., 1982; Wilhelm \& McMaster, 1995; Xue et al., 2004) using the data collected in the four planting dates (21 Jan. 2003, 12 Feb. 2003, 28 Feb. 2003, and 27 Mar. 2003). The estimated phyllochron was $18.4( \pm 4.2){ }^{\circ} \mathrm{C}$ day leaf ${ }^{1}$.

\section{Evaluation of models}

The values of NL predicted with the WE model and with the phyllochron model were compared with the observed NL values from the other ten planting dates (plantings 5-14, Table 1), which were independent data sets. We assumed that for both models the number of leaves at emergence was three leaves. This assumption was made because field observations showed that at emergence a rosette with 2-4 leaves were unfolded and visible at emergence. The statistics used to quantify model performance was the root mean square error (RMSE), calculated as (Janssen \& Heuberger, 1995):

$\operatorname{RMSE}=\left[\Sigma(\mathrm{p}-\mathrm{o})^{2} / \mathrm{n}\right]^{0.5}$

where $\mathrm{p}=$ predicted data, $\mathrm{o}=$ observed data, and $\mathrm{n}=$ number of observations. The unit of RMSE is the same as $p$ and o, i.e. leaves. The smaller the RMSE, the better the prediction.

\section{RESULTS AND DISCUSSION}

There was large variation in meteorological conditions during the leaf appearance phase for the 14 planting dates (Table 2). Average monthly minimum temperature was the lowest in August $2003\left(8.4^{\circ} \mathrm{C}\right)$ and average monthly maximum temperature was the highest in both January 2003 and January $2004\left(31.7^{\circ} \mathrm{C}\right)$. Precipitation varied from $21.7 \mathrm{~mm}$ in January 2004 to $355.0 \mathrm{~mm}$ and $357.3 \mathrm{~mm}$ in March 2003 and December 2003, respectively. Planting dates also resulted in plants with final leaf number on the main stem (FLN) varying from 12 to 28 leaves (data not shown). These distinct growing seasons and the main stem FLN provide a rich data set to evaluate the two LAR models.

Data from all planting dates used as independent data sets (plantings 5 to 14 , Table 1) were pooled to compare observed and predicted main stem NL with the phyllochron model and with the WE model (Fig-

Table 2 - Monthly average minimum, mean and maximum air temperatures, and accumulated precipitation during the two years of the experiment at Santa Maria, RS, Brazil.

\begin{tabular}{lcccc}
\hline \multirow{2}{*}{ Month/year } & \multicolumn{3}{c}{ Temperature } & Precipitation \\
\cline { 2 - 3 } & Minimum & Mean & Maximum & mm \\
\hline January/2003 & 19.9 & 25.8 & 31.7 & 177.8 \\
\hline February/2003 & 20.9 & 25.8 & 30.6 & 204.7 \\
\hline March/2003 & 18.9 & 23.6 & 28.2 & 355.0 \\
\hline April/2003 & 14.3 & 19.7 & 25 & 190.0 \\
\hline May/2003 & 12.1 & 17.7 & 23.4 & 69.1 \\
\hline June/2003 & 12.9 & 16.7 & 20.6 & 170.5 \\
\hline July/2003 & 9.6 & 14.3 & 19 & 73.9 \\
\hline August/2003 & 8.4 & 14.5 & 20.6 & 57.0 \\
\hline September/2003 & 10.9 & 16.7 & 22.6 & 193.4 \\
\hline October/2003 & 14.9 & 20.9 & 26.9 & 228.6 \\
\hline Novenber/2003 & 16.6 & 22.3 & 28 & 357.3 \\
\hline December/2003 & 17.3 & 22.5 & 27.6 & 21.7 \\
\hline January/2004 & 19.8 & 25.7 & 31.7 & 110.8 \\
\hline February/2004 & 17.9 & 23.9 & 30 & 101.5 \\
\hline March/2004 & 17.3 & 23.7 & 30.1 & 80.5 \\
\hline April/2004 & 16.4 & 22.2 & 28.1 & 72.1 \\
\hline May/2004 & 10.6 & 15.3 & 19.8 & 72.5 \\
\hline June/2004 & 11.7 & 16.7 & 21.6 & 94.5 \\
\hline July/2004 & 8.7 & 14.1 & 19.5 & 96.3 \\
\hline August/2004 & 10.7 & 16.2 & 21.7 & 24.5 \\
\hline September/2004 & 13.8 & 19.1 & & \\
\hline & & & \\
\hline
\end{tabular}


ure 3). The overall RMSE was 3.7 leaves with the phyllochron model, with most of the data being under predicted (Figure 3a). Predictions were greatly improved with the WE model (RMSE $=2.0$ leaves), with data spread around the 1:1 line (Figure 3b). A better performance of the WE model was observed for all the 10 planting dates. The RMSE varied from 1.4 to 6.9 leaves with the phyllochron model and from 1.0 to 3.4 leaves with the WE model (Table 3). Plantings 5 (12 Aug. 2003), 6 (15 Sept. 2003), and 14 (26 Aug. 2004) are recommended planting dates for the Spring growing season, and plantings 11 (27 Feb. 2004) and 12 (26 Mar. 2004) are recommended planting dates for the Fall growing season for local conditions. For these recommended planting dates, the RMSE with the WE model varied from 1.2 to 2.3 leaves and with the phyllochron model the RMSE varied from 2.8 to 3.5 leaves.

Plants of plantings 8 (20 Nov. 2003) and 9 (24 Dec. 2003) grew under extremely high temperatures for potato, with maximum temperatures reaching $35^{\circ} \mathrm{C}$ and above, during several days, especially in January 2004. Even in these unfavorable conditions the WE model performed well, with an RMSE of 1.5 and 2.8 leaves, compared to 2.3 and 6.9 leaves with the phyllochron model. The performance of the two LAR models throughout the growing season of two recommended planting dates (15 Sep. 2003 and 27 Feb. 2004) and in the 24 Dec. 2003 planting date is presented in Figure 4. The phyllochron model underpredicted the main stem NL during the entire period of leaf appearance phase for the three planting dates whereas the predictions with the WE model predictions were close to the observed data, mainly for the recommended planting dates.

Table 3 - Values of the root mean square error (RMSE, leaves) for the prediction of main stem number of emerged leaves of the potato cv. Asterix with the phyllochron model and the WE model for ten planting dates. Santa Maria, RS, Brazil, 2003/2004.

\begin{tabular}{lcc}
\hline Planting date & Phyllochron model & WE model \\
\hline $08 / 12 / 2003$ & 2.9 & 2.3 \\
$09 / 15 / 2003$ & 3.2 & 1.4 \\
$10 / 15 / 2003$ & 4.1 & 1.0 \\
$11 / 20 / 2003$ & 2.3 & 1.5 \\
$12 / 24 / 2003$ & 6.9 & 2.8 \\
$01 / 28 / 2004$ & 3.5 & 1.3 \\
$02 / 27 / 2004$ & 2.8 & 1.2 \\
$03 / 26 / 2004$ & 2.8 & 1.5 \\
$04 / 26 / 2004$ & 1.4 & 3.4 \\
$08 / 26 / 2004$ & 3.5 & 2.3 \\
\hline
\end{tabular}
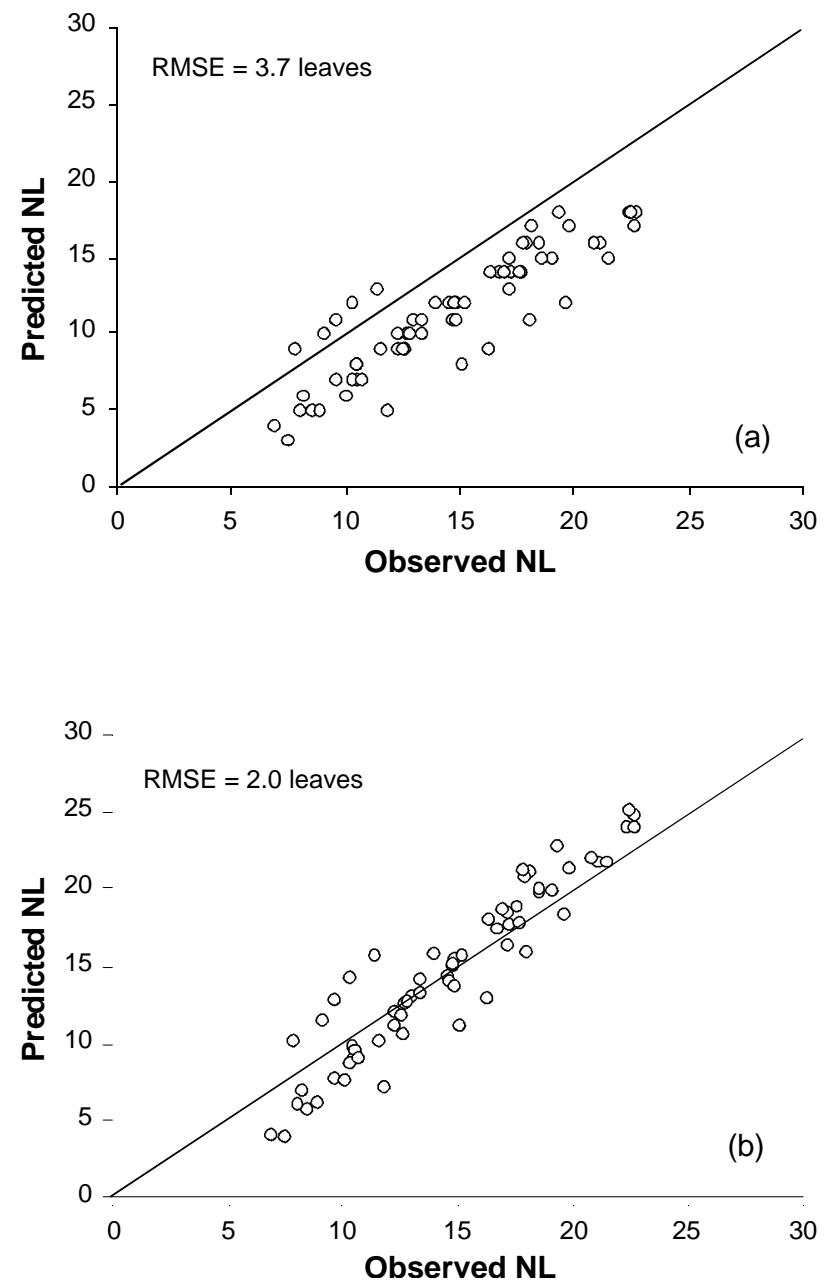

Figure 3 - Predicted versus observed main stem leaf number (NL) of potato cv. Asterix, using the phyllochron model (a) and the WE model (b). Data are pooled for ten planting dates (planting 5-14, Table 1). Santa Maria, RS, Brazil, 2003-2004. The solid line the 1:1 line.

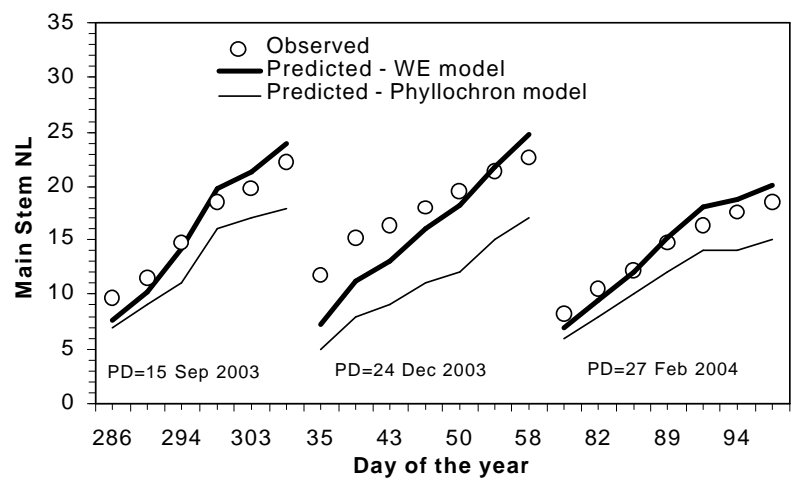

Figure 4 - Observed main stem number of leaves (NL) of potato cv. Asterix, and NL predicted with the WE model and with the phyllochron model for three planting dates (PD) at Santa Maria, RS, Brazil, during 2003 and 2004. 
The predictions of main stem NL with the phyllochron model were off by more than five leaves in all but one planting date (26 Apr. 2004). If the predictions of leaf number are off by more than five leaves, this difference can have a considerable impact on the predictions of other processes based on the number of leaves in potato. For example, if the duration of the emergence-flag leaf appearance phase is calculated based on phyllochron and assuming a main stem FLN of 25 (as observed in some of the planting dates of this study) an error of five leaves is an error of 92 ${ }^{\circ} \mathrm{C}$ day, which represents several calendar days, mainly when temperatures are close to the base temperature for potato $\left(7^{\circ} \mathrm{C}\right)$. Branching is related to main stem NL in potato (Bätz et al., 1980; Vos \& Biemond, 1992), and an error in the prediction of NL will cause errors in the prediction of the branching date and leaf appearance on branches, which will have further impact on the prediction of the whole plant leaf number and leaf area.

The poorest performance of the phyllochron model in predicting potato NL in this study is probably because this model uses the thermal time approach as a measure of time with the assumption of a linear relationship between temperature and development (Xue et al., 2004; Figure 2). This assumption is not completely realistic from a biological view point. Biological processes, including plant development, respond to temperature in a non-linear fashion (Yin et al., 1995; Granier \& Tardien, 1998; Bonhomme, 2000), with only a small portion of the response being linear (Shaykewich, 1995; Streck et al., 2003a; 2003b; Wang \& Engel, 1998). The linear response of plant development to temperature occurs only at intermediate values of the range from the minimum or base temperature to the optimum temperature for development. These temperature conditions are often found when the crop is planted at the recommended planting date, and in this case the thermal time approach often works well enough. However, when the temperature is close to the cardinal temperatures, the thermal time does not work properly. This was the case in our study where the RMSE was the highest (6.9 leaves) with the phyllochron when potato was planted on 24 Dec 2003, Summer time in the Southern Hemisphere. The WE model, which uses a non-linear temperature response function, predicted NL in this planting date much better (Figure 4), with an RMSE of only 2.8 leaves. Similar results were reported by Xue et al. (2004) with winter wheat.

In this application of the WE model there was only one genotype dependent coefficient, i.e. LARmax. This coefficient was easily estimated and has biological meaning and operational definition. The cardinal temperatures for the temperature response function were derived from other genotypes described in the literature, and the WE model performed well in simulating the main stem NL of the potato cultivar Asterix for different planting dates. These results indicate two important features of the WE model that are sought for any crop simulation model: generality and robustness while maintaining accurate predictions.

\section{CONCLUSIONS}

Predictions of the main stem NL of potato cv. Asterix were poor with the phyllochron model and were greatly improved with the WE model. The overall RMSE of the predictions with the WE model was 2.0 leaves, a $54 \%$ improvement over the phyllochron model.

\section{ACKNOWLEDGMENTS}

To CNPq for scholarships to N.A. Streck, D.A. Bisognin and A.B. Heldwein, to FAPERGS for scholarship to I. Lago, and to CAPES for scholarship to F.L.M. de Paula.

\section{REFERENCES}

ARNOLD, C.Y. Maximum-minimum temperatures as a basis for computing heat units. Proceedings of the American Society for Horticultural Sciences, v.76, p.682-692, 1960.

BÄTZ, W.; MEIER, U.; RADTKE, W.; SCHÖBER, B.; SEIDEWITZ, L.; STEINBERGER, J. Entwicklungsstadien der kartoffel: Biologische Bundesanstalt fur land-und forstwirtschaft. Berlin: Merkablatt, 1980.

BISOGNIN, D. Recomendações técnicas para o cultivo da batata no Rio Grande do Sul e Santa Catarina. Santa Maria: UFSM, 1996. $64 p$.

BONHOMME, R. Bases and limits to using 'degree day' inits. European Journal of Agronomy, v.13, p.1-10, 2000.

CAO, W.; TIBBITTS, T.W. Leaf emergence on potato stems in relation to thermal time. Agronomy Journal, v.87, p.474-477, 1995.

FAO. FAOSTAT data 2005. Avaliable at: http//faostat.Fao.org/faostat. Accessed on: 25 Jul. 2005.

FORTSTHOFER, E.L.; SILVA, P.R.F.; ARGENTA, G.; STRIEDER, M.L.; SUHRE, E.; RAMBO, L. Agronomic and phenological development of three maize hybrids at three sowing dates. Ciência Rural, v.34, p.1341-1348, 2004.

GILMORE, E.C.; ROGERS, J.S. Heat units as a method of measuring maturity in corn. Agronomy Journal, v.50, p.611-615, 1958.

GRANIER, C.; TARDIEN, F. Is thermal time adequate for expressing the effects of temperature on sunflower leaf development? Plant Cell Environment, v.21, p.695-703, 1998.

HAWKES, J.G. The potato: evolution, biodiversity and genetic resources. Washington: Smithsonian Institution, 1990. 259p.

HAWKES, J.G. Origins of cultivated potatoes and species relationships. In: BRADSHAW, J.E.; MACKAY, R.R. (Ed.) Potato genetics. Cambridge: CAB International, 1994. cap.1, p.3-42.

HODGES, T. Crop growth simulation and the role of phenological models. In: HODGES, T. (Ed.). Predicting crop phenology. Boston: CRC Press, 1991. cap.1, p.3-5.

IBGE. Levantamento sistemático da produção agrícola, confronto das safras de 2003 e das estimativas para 2004. Available at: http:/ /www.ibge.com.br. Acessed on: 22 Nov. 2004. 
JANSSEN, P.H.M.; HEUBERGER, P.S.C. Calibration of processoriented models. Ecological Modelling, v.83, p.55-56, 1995.

KIRBY, E.J. Factors affecting rate of leaf emergence in barley and wheat. Crop Science, v.35, p.11-19, 1995.

KLEPPER, B.; RICKMAN, R.W.; PETERSON, C.M. Quantitative characterization of vegetative development in small cereal grains. Agronomy Journal, v.74, p.789-792, 1982.

LEE, C.K.; LEE, B.W.; SHIN, J.C.; YOON, Y.H. Heading date and final leaf number as affected by sowing date and prediction of heading date based on leaf appearance model in rice. Korean Journal of Crop Science, v.46, p.195-201, 2001.

LOPES, C.A.; BUSO, J.A. Cultivo de batata (Solanum tuberosum L.). Brasília: Embrapa Hortaliças, 1997. 35p.

MANRIQUE, L.M. Potato production in the tropics. Honolulu: Manrique International Agrotech, 2000. 144p.

MATTHEWS, R.B.; HUNT, L.A. GUMCAS: a model describing the growth of cassava (Manihot esculenta L. Crantz). Field Crops Research, v.39, p.69-84, 1994.

McMASTER, G.S. Phytomers, phyllochrons, phenology and temperate cereal development. Journal of Agricultural Science Cambridge, v.143, p.137-150, 2005.

McMASTER, G.S.; WILHELM, W.W. Growing degree-days: One equation, two interpretations. Agricultural and Forest Meteorology, v.87, p.291-300, 1997.

McMASTER, G.S.; KEPPLER, B.; RICKMAN, R.W.; WILHELM, W.W.; WILLIS, W.O. Simulation of shoot vegetative development and growth of unstressed winter wheat. Ecological Modeling, v.53, p.189-204, 1991.

NYENDE, A.B.; SCHITTENHELM, S.; MIX-WAGNER, G.; GREEF, J.M. Yield and canopy development of field grown potato plants dereved from synthetic seeds. European Journal of Agronomy, v.22, p.175-184, 2005.

SANDS, P.J.; HACKETT, C.; NIX, H.A. A model of the development and bulking of potatoes (Solanum tuberosum L.). I - Derivation from well-managed field crops. Field Crops Research, v.2, p.309-331, 1979.
SHAYKEWICH, C.F. An appraisal of cereal crop phenology modeling. Canadian Journal of Plant Science, v.75, p.329-341, 1995.

STRECK, N.A.; WEISS, A.; XUE, Q.; BAENZIGER, P.S. Improving predictions of developmental stages in winter wheat: A modified Wang and Engel model. Agricultural and Forest Meteorology, v.115, p.139-150, 2003a.

STRECK, N.A.; WEISS, A.; XUE, Q.; BAENZIGER, P.S. Incorporating a chronology response function into the prediction of leaf appearance rate in winter wheat. Annals of Botany, v.92, p.181-190, 2003b.

VOS, J.; BIEMOND, J. Effects of Nitrogen on the development and growth of the potato plant. 1. Leaf appearance, expansion growth, life spans of leaves and stem branching. Annals of Botany, v.70, p.27-35, 1992

WANG, E.; ENGEL, T. Simulation of phenological development of wheat crops. Agricultural Systems, v.58, p.1-24, 1998.

WESTERMANN, D.T.; KLEINKOPF, G.E. Nitrogen requirements of potatoes. Agronomy Journal, v.77, p.616-621, 1985.

WILHELM, W.W.; MCMASTER, G.S. Importance of the phyllochron in studying development and growth in grasses. Crop Science, v.35, p.1-3, 1995.

XUE, Q.; WEISS, A.; BAENZIGER, P.S. Predicting leaf appearance in field grown winter wheat: evaluating linear and non-linear models. Ecological Modelling, v.175, p.261-270, 2004.

YIN, X.; KROPFF, M.J.; McLAREN, G.; VISPERAS, R.M. A nonlinear model for crop development as a function of temperature. Agricultural and Forest Meteorology, v.77, p.1-16, 1995.

Received February 08, 2006

Accepted January 14, 2007 